\title{
Esculentin-2CHa(1-30) and its analogues: stability and mechanisms of insulinotropic action
}

\author{
Srividya Vasu', Mary K McGahon², R Charlotte Moffett', Tim M Curtis'2, \\ J Michael Conlon', Yasser H A Abdel-Wahab' ${ }^{1}$ and Peter R Flatt ${ }^{1}$
}

ISAAD Centre for Pharmacy \& Diabetes, School of Biomedical Sciences, University of Ulster, Coleraine, UK

${ }^{2}$ Centre for Experimental Medicine, Queens University of Belfast, Belfast, UK
Correspondence should be addressed to $S$ Vasu

Email

s.vasu@outlook.com

\begin{abstract}
The insulin-releasing effects, cellular mechanisms of action and anti-hyperglycaemic activity of 10 analogues of esculentin-2CHa lacking the cyclic C-terminal domain (CKISKQC) were evaluated. Analogues of the truncated peptide, esculentin-2CHa(1-30), were designed for plasma enzyme resistance and increased biological activity. Effects of those analogues on insulin release, cell membrane integrity, membrane potential, intracellular $\mathrm{Ca}^{2+}$ and CAMP levels were determined using clonal BRIN-BD11 cells. Their acute effects on glucose tolerance were investigated using NIH Swiss mice. D-Amino acid substitutions at positions 7(Arg), 15(Lys) and 23(Lys) and fatty acid (L-octanoate) attachment to Lys at position 15 of esculentin-2 $\mathrm{CHa}(1-30)$ conveyed resistance to plasma enzyme degradation whilst preserving insulin-releasing activity. Analogues, [D-Arg ${ }^{7}, \mathrm{D}-\mathrm{Lys}^{15}{ }^{15}, \mathrm{D}-\mathrm{Lys}^{23}{ }^{23}$-esculentin-2CHa(1-30) and Lys ${ }^{15}$-octanoate-esculentin$2 \mathrm{CHa}(1-30)$, exhibiting most promising profiles and with confirmed effects on both human insulin-secreting cells and primary mouse islets were selected for further analysis. Using chemical inhibition of adenylate cyclase, protein kinase $C$ or phospholipase $C$ pathways, involvement of PLC/PKC-mediated insulin secretion was confirmed similar to that of CCK-8. Diazoxide, verapamil and $\mathrm{Ca}^{2+}$ omission inhibited insulin secretion induced by the esculentin-2 $\mathrm{CHa}(1-30)$ analogues suggesting an action on $\mathrm{K}_{\mathrm{ATP}}$ and $\mathrm{Ca}^{2+}$ channels also. Consistent with this, the analogues depolarised the plasma membrane and increased intracellular $\mathrm{Ca}^{2+}$. Evaluation with fluorescent-labelled esculentin$2 \mathrm{CHa}(1-30)$ indicated membrane action, with internalisation; however, patch-clamp experiments suggested that depolarisation was not due to the direct inhibition of $\mathrm{K}_{\text {ATP }}$ channels. Acute administration of either analogue to NIH Swiss mice improved glucose tolerance and enhanced insulin release similar to that observed with GLP-1. These data suggest that multi-acting analogues of esculentin-2CHa(1-30) may prove useful for glycaemic control in obesity-diabetes.
\end{abstract}

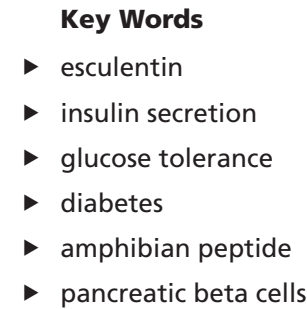

Journal of Endocrinology (2017) 232, 423-435 


\section{Introduction}

Incidence of type 2 diabetes is constantly on the rise, owing to an increase in consumption of a Western diet, sedentary lifestyle, obesity and ageing population (Stumvoll et al. 2008, McCarthy 2011). Current therapies targeting beta cell secretory function and/or insulin action offer metabolic benefits, but due to the inability to restore normal glycaemic control, diabetes-associated complications arise including cardiovascular disease, neuropathy, nephropathy and retinopathy (McCarthy 2011, Parkes et al. 2013, Kahn et al. 2014). As a result, there is a constant need for development of new, improved therapeutic agents to complement or replace existing antidiabetic drugs. Peptide hormone therapeutics and various glucagon-like peptide-1 (GLP-1 mimetics) have been strongly promoted over the past few years (Kahn et al. 2014, Irwin \& Flatt 2015). This approach has several potential advantages over development of small-molecule drugs, providing greater specificity and improved safety (Parkes et al. 2013).

In the 1980s, the search for bioactive agents in venoms of insects and reptiles led to the isolation and characterisation of exendin-4 from the salivary secretions of Heloderma suspectum (Gila monster) (Conlon et al. 2006). This peptide has been shown to stimulate insulin secretion and exert a range of glucoregulatory actions in a fashion similar to incretin hormone, GLP-1 (Parkes et al. 2013). Subsequently, long-acting GLP-1 mimetics with good clinical efficacy and acceptable benefit-risk profiles have been developed for the treatment of patients with type 2 diabetes (Irwin \& Flatt 2015). The search for naturally occurring bioactive agents has continued to date. Skin secretions of frogs and toads are a potentially valuable source of peptides that hold great therapeutic potential. Such molecules synthesised in the skin of amphibians (particularly the hylidae (Nicolas \& El Amri 2009, Jackway et al. 2011), pipidae (Mechkarska et al. 2010) and Ranidae (Conlon 2008, 2011) families) are well known for their antimicrobial, antiviral, anti-tumour, immunomodulatory and chemoattractive properties (Conlon et al. 2014). In addition, we have demonstrated that some of these host defence peptides isolated from frog skin secretions were insulinotropic in vitro and could improve glucose tolerance in animal models in vivo (Conlon et al. 2014).

Esculentin-2CHa (GFSSIFRGVAKFASKGLGKDLAKL GVDLVACKISKQC), isolated from norepinephrinestimulated skin secretions of the Chiricahua leopard frog, Lithobates chiricahuensis (Ranidae), has been shown to exhibit potent antimicrobial activity against clinical isolates of multidrug-resistant strains of Staphylococcus aureus, Acinetobacter baumannii, and Stenotrophomonas maltophilia (Conlon et al. 2011). In addition, this bioactive peptide also stimulated interleukin-10 (IL-10) release by mouse lymphoid cells and exerted cytotoxicity against human non-small-cell lung adenocarcinoma A549 cells with low haemolytic activity against human erythrocytes (Attoub et al. 2013). Increasing the cationicity of the peptide with L-lysine substitution of $\mathrm{Asp}^{20}$ and $\mathrm{Asp}^{27}$ residues enhanced antimicrobial activity, whereas removal of either the hydrophobic N-terminal hexapeptide (GFSSIF) or the cyclic C-terminal domain (CKISKQC) and serine substitution of $\mathrm{Cys}^{31}$ and $\mathrm{Cys}^{37}$ residues decreased the antimicrobial potency (Attoub et al. 2013).

We recently reported the anti-diabetic effects of an analogue of esculentin-2CHa ([ $\left.\mathrm{Lys}^{28}\right]$-esculentin-2CHa) in high-fat-fed diabetic mice (Ojo et al. 2015). Our previous observations indicate that any modification of frog skin peptides resulting in loss or reduction of antimicrobial activity also resulted in compromise of insulinotropic action. Interestingly, our preliminary observations revealed that loss of antimicrobial activity associated with removal of the cyclic C-terminal domain of esculentin$2 \mathrm{CHa}$ was not accompanied by abolition of insulinotropic actions in vitro. In other words, the truncated form of esculentin-2CHa with 30 amino acid residues (esculentin2CHa-GA30) and lacking the C-terminal disulphide bond stimulated insulin release from BRIN-BD11 cells.

Based on this and with a view to generating more easily synthesised/cost-effective forms of esculentin-2CHa with potential as a possible new class of therapeutic peptides for diabetes, we designed a family of 10 analogues of esculentin-2CHa(1-30) as indicated in Table 1. D-Isomers of naturally occurring amino acids were substituted at positions 7, 15 and 23 (Peptides 2-6) to confer resistance to endopeptidases based on the observed degradation pattern of the peptide in plasma. In addition, lysine residues at positions 15 and 23 were substituted with L-ornithine with a view to increasing metabolic stability (Peptide 7) and amidation of C-terminus (Peptide 8). To prolong half-life in the circulation (by facilitating binding to serum albumin), analogues were synthesised with a C-8 fatty acid (octanoate) attached to the lysine residue at position 15 or 23 (Peptides 9 or 10). Using the parent esculentin-2CHa(1-30) (Peptide 1) as positive control, we investigated these various modified analogues

Published by Bioscientifica Ltd. 
Table 1 Amino acid sequences and molecular masses of esculentin-2CHa, esculentin-2CHa(1-30) and substituted analogues.

\begin{tabular}{|c|c|}
\hline $\begin{array}{l}\text { Peptide } \\
\text { No. }\end{array}$ & Name \\
\hline & Esculentin-2CHa \\
\hline 1 & Esculentin-2CHa(1-30) \\
\hline 2 & [D-Arg']-esculentin-2CHa(1-30) \\
\hline 3 & [D-Lys ${ }^{15}$-esculentin-2CHa(1-30) \\
\hline 4 & [D-Lys 23 ]-esculentin-2CHa(1-30) \\
\hline 5 & [D-Lys $\left.{ }^{15}, \mathrm{D}-\mathrm{Lys}^{23}\right]$-esculentin-2CHa(1-30) \\
\hline 6 & {$\left[\mathrm{D}-\mathrm{Arg}^{7}, \mathrm{D}-\mathrm{Lys}^{15}, \mathrm{D}-\mathrm{Lys}^{23}\right]$-esculentin-2CHa(1-30) } \\
\hline 7 & {$\left[\mathrm{~L}-\mathrm{Orn}{ }^{15}, \mathrm{~L}-\mathrm{Orn}{ }^{23}\right]$-esculentin-2CHa(1-30) } \\
\hline 8 & Esculentin-2CHa(1-30)- $\mathrm{NH}_{2}$ \\
\hline 9 & Lys $^{15}$-octanoate-esculentin-2CHa(1-30) \\
\hline 10 & Lys 23 -octanoate-esculentin-2CHa(1-30) \\
\hline
\end{tabular}

\begin{tabular}{|c|c|}
\hline $\begin{array}{l}\text { Theoretical } \\
\text { molecular } \\
\text { mass (Da) }\end{array}$ & $\begin{array}{l}\text { Measured } \\
\text { molecular } \\
\text { mass (Da) }\end{array}$ \\
\hline $\begin{array}{l}3841.6 \\
3052.6\end{array}$ & $\begin{array}{c}- \\
3053.7\end{array}$ \\
\hline 3052.6 & 3053.1 \\
\hline 3052.6 & 3052.0 \\
\hline 3052.6 & 3054.0 \\
\hline 3052.6 & 3053.8 \\
\hline 3052 & 3053.9 \\
\hline 3024.5 & 3026.3 \\
\hline 3051.6 & 3051.0 \\
\hline 3178.6 & 3177.5 \\
\hline 3178.6 & 3176.6 \\
\hline
\end{tabular}

for enzymatic stability, insulinotropic effects, cellular mechanisms of action and acute anti-hyperglycaemic effects in vivo.

\section{Materials and methods}

\section{Peptide synthesis and purification}

Synthetic esculentin-2CHa(1-30) and analogues (Table 1) were purchased (>95\% pure) from GL Biochem Ltd (Shanghai, China) and purified to near homogeneity (>98\% pure) by reversed-phase HLPC on a $\left(2.2 \times 25 \mathrm{~cm}^{2}\right)$ Vydac 218TP1022 (C18) column equilibrated with acetonitrile/water/trifluoroacetic acid (TFA) (21.0/78.9/0.1 $\mathrm{v} / \mathrm{v})$ mobile phase at a flow rate of $1 \mathrm{~mL} / \mathrm{min}$. The concentration of acetonitrile in the eluting buffer was raised to $56 \%(\mathrm{v} / \mathrm{v})$ over $60 \mathrm{~min}$. The molecular masses of the peptides were confirmed using MALDI-TOF mass spectrometry (Table 1). Other peptides including the enzyme-resistant form of CCK-8, pggCCK-8 (Irwin et al. 2013), were purchased from American Peptide Company (Sunnyvale, CA, USA).

\section{Peptide degradation studies}

Susceptibility of esculentin-2CHa(1-30) and related peptides to plasma proteolytic enzymes was determined by incubating the peptides with plasma $(10 \mu \mathrm{L})$ from fasted NIH Swiss mice in $50 \mathrm{mM}$ triethanolamine- $\mathrm{HCl}$ buffer ( $\mathrm{pH} 7.8)$ at $37^{\circ} \mathrm{C}\left(\mathrm{O}^{\prime}\right.$ Harte et al. 2001) for $0 / 8 \mathrm{~h}$. The reactions were stopped by adding $10 \%(\mathrm{v} / \mathrm{v})$ TFA/water $(10 \mu \mathrm{L})$. Separation of intact and degraded products was carried out using reversed-phase HPLC with a Vydac C18 column equilibrated with $0.12 \%(\mathrm{v} / \mathrm{v}) \mathrm{TFA} /$ water at a flow rate of $1.0 \mathrm{~mL} / \mathrm{min}$. The concentration of acetonitrile in the eluting solution was increased over a linear gradient from 0 to $28 \%$ in $10 \mathrm{~min}$, to $56 \%$ in $20 \mathrm{~min}$ and from $56 \%$ to $70 \%$ in $5 \mathrm{~min}$. MALDI-TOF mass spectrometry was used to ascertain the molecular masses of both intact and degraded products.

\section{Cell culture}

Insulin-secreting BRIN-BD11 rat clonal beta cells and 1.1B4 human clonal beta cells were routinely cultured in RPMI-1640 medium supplemented with 10\% (v/v) FBS and $1 \%(\mathrm{v} / \mathrm{v})$ antibiotics: penicillin $(100 \mathrm{U} / \mathrm{mL})$ and streptomycin $(0.1 \mathrm{mg} / \mathrm{mL})$. The generation, culture and characteristics of these two cell lines have been described previously (McClenaghan et al. 1996, McCluskey et al. 2011).

\section{In vitro insulin-releasing studies}

In vitro insulin-releasing effects of esculentin-2CHa(1-30) and its analogues were assessed using clonal beta cell lines as well as isolated mouse pancreatic islets. Firstly, BRIN-BD11 cells were incubated with the peptides in the concentration range $\left(1 \times 10^{-12}-3 \times 10^{-6} \mathrm{M}\right)$ in Krebs-Ringer bicarbonate buffer (KRBB) containing $5.6 \mathrm{mM}$ glucose for $20 \mathrm{~min}$ at $37^{\circ} \mathrm{C}$ as previously described (Abdel-Wahab et al. 2008, Mechkarska et al. 2011, Ojo et al. 2011). Effects of established modulators of insulin release, removal of extracellular $\mathrm{Ca}^{2+}$ and inhibitors of phospholipase C (U73122) and adenylate cyclase (NKY80) were also tested (Abdel-Wahab et al. 2008, Mechkarska et al. 2011, Ojo et al. 2011). Plasma membrane integrity was assessed by measuring lactate dehydrogenase (LDH) in cell incubation buffer using CytoTox 96 nonradioactive cytotoxicity assay kit (Promega) according 
to the manufacturer's instructions. In a second set of experiments, insulin-releasing effects of esculentin$2 \mathrm{CHa}(1-30)$ and selected analogues were examined over a similar concentration range using 1.1B4 human clonal beta cells (McCluskey et al. 2011, Green et al. 2015). In a third set of experiments, pancreatic islets isolated from NIH Swiss mice by collagenase digestion (Gotoh et al. 1985) were incubated with $10^{-6}$ and $10^{-8} \mathrm{M}$ of esculentin$2 \mathrm{CHa}(1-30)$ and selected analogues for $1 \mathrm{~h}$ in KrebsRinger bicarbonate (KRB) buffer supplemented with 3 or $20 \mathrm{mM}$ glucose. Other experiments detailed below were conducted at peptide concentration of $10^{-6} \mathrm{M}$, which elicited prominent insulin-secretory effects. Insulin release was measured by radioimmunoassay (Flatt \& Bailey $1981 a, b$ ) using mouse or human insulin standards as appropriate.

\section{Membrane potential studies and intracellular calcium $\left(\left[\mathrm{Ca}^{2+}\right]_{i}\right)$}

Effects of esculentin-2CHa(1-30) and its analogues on membrane potential and intracellular calcium $\left[\mathrm{Ca}^{2+}\right]_{\mathrm{i}}$ were assessed using BRIN-BD11 cells (FLIPR membrane or calcium assay kit, Molecular Devices, USA) as previously described (Miguel et al. 2004). BRIN-BD11 cells were incubated with Krebs-Ringer bicarbonate buffer containing $5.6 \mathrm{mM}$ glucose. Esculentin-2CHa(1-30) and its analogues were added, with calcium mobilisation data collected and analysed using Softmax Pro software (Miguel et al. 2004).

\section{Membrane binding and patch-clamp electrophysiology For membrane-binding studies,} BRIN-BD11 cells were seeded onto polysine-coated slides (40,000 cells/slide) and cultured overnight. Media was replaced with KRBB containing $1 \mu \mathrm{M}$ FITC-esculentin$2 \mathrm{CHa}(1-30)$ and incubated for 5-90 min. Coverslips were washed with PBS, rapidly transferred to the recording bath (containing fresh PBS) mounted on an inverted microscope (Leica DMI6500B) coupled to a Leica TCS SP5 II confocal. Cells were excited by an argon laser $(488 \mathrm{~nm})$ and simultaneously viewed on the transmitted light channel to allow assessment of the distribution of FITC-esculentin-2CHa(1-30) on plasma membrane and cytosolic compartments of the cells. Ionic currents were recorded from BRIN-BD11 pancreatic $\beta$-cells using the whole-cell mode of the patch-clamp technique as previously described (Ojo et al. 2016). Amphotericin B was included in the pipette solutions to perforate the membrane and reduce current run-down such that currents were stable for the duration of the recording (Ojo et al. 2016). Current densities were calculated by dividing current amplitudes by the whole-cell capacitance $(6-19 \mathrm{pF})$. Solutions containing drugs were applied using a gravity-driven perfusion system with an exchange time of approximately $1 \mathrm{~s}$ (Scholfield \& Curtis 2000). $\mathrm{K}_{\text {ATP }}$ currents were elicited by ramp protocols from +20 to $-80 \mathrm{mV}$ applied over $1 \mathrm{~s}$ from a holding potential of $0 \mathrm{mV}$ using high $\mathrm{K}^{+}$external solution (containing in $\mathrm{mM}$ : $130 \mathrm{KCl}, 10 \mathrm{TEACl}, 2.5$ Glucose, $1.3 \mathrm{MgCl}_{2}, 2 \mathrm{CaCl}_{2}, 10$ HEPES, pH 7.4 with $\mathrm{NaOH}) .100 \mathrm{nM}$ penitrem $\mathrm{A}, 1 \mathrm{mM}$ 4,4'-diisothiocyanatostilbene-2,2'-disulfonate (DIDS) and $1 \mu \mathrm{M}$ nimodipine were added to inhibit $\mathrm{BK}, \mathrm{Cl}^{-}$and L-type $\mathrm{Ca}^{2+}$ channels, and a $\mathrm{K}^{+}$-based internal (pipette) solution was used $\left(130 \mathrm{KCl}, 1 \mathrm{MgCl}_{2}, 0.045 \mathrm{CaCl}_{2}, 1\right.$ EGTA, 10 HEPES, pH 7.2 with $\mathrm{NaOH}$ ). $\mathrm{K}_{\mathrm{ATP}}$ channel opening was stimulated with $200 \mu \mathrm{M}$ diazoxide prior to and during the application of $1 \mu \mathrm{M}$ [D-Arg ${ }^{7}, \mathrm{D}-\mathrm{Lys}^{15}, \mathrm{D}-\mathrm{Lys}^{23}$ ]-esculentin2CHa(1-30) (Peptide 6).

In vivo studies Adult male National Institutes of Health (NIH) Swiss mice were housed individually in an air-conditioned room $\left(22 \pm 2^{\circ} \mathrm{C}\right)$ with a 12-h light:12-h darkness cycle and maintained on a standard rodent diet (Trouw Nutrition, Cheshire, UK), with food and water available ad libitum. For acute in vivo studies, overnight fasted mice received an intraperitoneal injection of glucose alone $(18 \mathrm{mmol} / \mathrm{kg}$ body weight) or in combination with esculentin-2CHa(1-30) or its analogues $(75 \mathrm{nmol} / \mathrm{kg}$ body weight). This dose was chosen on the basis of results in previous studies examining the glucoregulatory effects of amphibian skin peptides (Conlon et al. 2014). A small dose-response study was conducted using GLP-1 and the two most prominent glucose-lowering peptides (Peptides 6 and 9). Blood samples were collected before injection and at times indicated in the Figures. All animal experiments were carried out in accordance with the UK Animals (Scientific Procedures) Act 1986 and 'Principles of Laboratory Animal Care' (NIH publication no. 86-23, revised 1985).

\section{Statistical analysis}

Results were analysed using GraphPad Prism Software (version 6.0) and presented as mean \pm S.E.M. Statistical analyses were performed using Student's t-test (nonparametric) or one-way ANOVA followed by Bonferroni or Student-Newman-Keuls post hoc test wherever applicable.

Published by Bioscientifica Ltd. 
Area under the curve (AUC) analysis was performed using the trapezoidal rule with baseline correction. Membrane current-voltage relations were compared using 2-way repeated measures ANOVA with Bonferroni post hoc test. Results were considered significant if $P<0.05$.

\section{Results}

\section{Plasma stability of esculentin-2CHa(1-30) and analogues}

Degradation of esculentin-2CHa(1-30) (Peptide 1) exposed to mouse plasma was $93 \%$ in $8 \mathrm{~h}$ (Table 2). Examination of degradation products by mass spectrometry suggests that the native peptide is cleaved by enzymes at the following sites: between Phe ${ }^{6}$ and Arg7, Arg7 and Gly8, Lys $^{11}$ and Phe ${ }^{12}$, Ser ${ }^{14}$ and Lys ${ }^{15}$, Leu ${ }^{17}$ and Gly ${ }^{18}$, Ala ${ }^{22}$ and Lys ${ }^{23}$ and $\mathrm{Leu}^{28}$ and $\mathrm{Val}^{29}$. Substitution with D-isomers of residues at position 7 (Peptide 2), position 15 (Peptide 3) and positions 7, 15 and 23 (Peptide 6) conferred resistance to degradation, with degradation ranging between 24 and 59\% (Table 2). Substitution with D-lysine residues at position 23 (Peptide 4) and at positions 15 and 23 (Peptide 5) reduced degradation to approximately $80 \%$ (Table 2 ). Peptide 6 was cleaved only at Lys ${ }^{11}$ and Phe ${ }^{12}$ and Leu ${ }^{28}$ and $\mathrm{Val}^{29}$ compared to esculentin-2Cha-GA30; thus, substitution of residues with D-isomers at these positions protected the sites from enzymatic cleavage. Substitution of lysine residues at positions 15 and 23 with L-ornithine (Peptide 7) and amidation of C-terminus (Peptide 8) did not confer resistance to degradation (Table 2). Addition of a C-8 fatty acid to lysine residue at position 15 (Peptide 9) or 23 (Peptide 10) conferred resistance to degradation (62 and 79\%, respectively, Table 2), with cleavage only at sites between $\mathrm{Arg}^{7}$ and $\mathrm{Gly}^{8}, \mathrm{Ala}^{22}$ and $\mathrm{Lys}^{23}$ and $\mathrm{Leu}^{24}$ and $\mathrm{Gly}^{25}, \mathrm{Arg}^{7}$ and Gly ${ }^{8}$ and Leu ${ }^{24}$ and Gly ${ }^{25}$, respectively.

\section{Insulinotropic actions of esculentin-2 $\mathrm{CHa}(1-30)$ and analogues}

Esculentin-2CHa(1-30) (Peptide 1) and analogues stimulated insulin release from BRIN-BD11 cells significantly compared to respective control at glucose $(5.6 \mathrm{mM})(P<0.05, P<0.01, P<0.001$, Table 2$)$. Substitution of residues at position 7 (Peptide 2), position 15 (Peptide 3), position 23 (Peptide 4) and positions 7 and 15 (Peptide 5 ) with respective D-isomers significantly increased insulin release from BRIN-BD11 cells $(P<0.01, P<0.001$, Table 2$)$. Substitution with D-isomers at positions 7,15 and 23 (Peptide 6) or with lysine residues at positions 15 and 23 with L-ornithine (Peptide 7) significantly increased insulin release from BRIN-BD11 cells compared with esculentin$2 \mathrm{CHa}(1-30)$ (Peptide 1) $(P<0.001$, Table 2). Amidation of C-terminus (Peptide 8) did not markedly affect insulin output from BRIN-BD11 cells compared to that from parent peptide (Table 2). Addition of a C-8 fatty acid to lysine residue at position 15 (Peptide 9) or 23 (Peptide 10) markedly increased insulin release from BRIN-BD11 cells $(P<0.001$, Table 2$)$, with effects of Peptide 9 significantly greater than those of esculentin-2CHa(1-30) $(P<0.01$, Table 2$)$. For native and all peptide analogues

Table 2 Degradation of esculentin-2CHa(1-30) peptides in plasma and effects on insulin and LDH release from clonal BRIN BD11 cells compared with established secretagogues.

\begin{tabular}{|c|c|c|c|c|}
\hline \multirow[b]{2}{*}{ Secretagogue/peptide } & \multirow[b]{2}{*}{$\begin{array}{l}\% \text { Degradation } \\
(8 \mathrm{~h} \text { in mouse plasma) }\end{array}$} & \multicolumn{3}{|c|}{ BRIN-BD11 cells } \\
\hline & & $\begin{array}{l}\text { Insulin release } \\
\text { (ng/million cells/20 } \mathrm{min})\end{array}$ & $\begin{array}{l}\text { Threshold concentration } \\
\qquad(\mathrm{M})\end{array}$ & $\begin{array}{l}\text { LDH release } \\
\text { (\% of control) }\end{array}$ \\
\hline Glucose (5.6 mM) & - & $0.75 \pm 0.04$ & - & $102.8 \pm 5.4$ \\
\hline Glucose (16.7 mM) & - & $1.36 \pm 0.10 * * *$ & - & $106.9 \pm 1.3$ \\
\hline Alanine $(10 \mathrm{mM})$ & - & $5.00 \pm 0.50 * * *$ & - & $106.1 \pm 1.8$ \\
\hline GLP-1(7-36) $\mathrm{NH}_{2}\left(10^{-6} \mathrm{M}\right)$ & - & $1.96 \pm 0.17 * * *$ & - & $94.7 \pm 5.3$ \\
\hline Peptide $1\left(3 \times 10^{-6} \mathrm{M}\right)$ & 93 & $1.32 \pm 0.04 * * *$ & $10^{-7}$ & $105.9 \pm 5.7$ \\
\hline Peptide $2\left(3 \times 10^{-6} \mathrm{M}\right)$ & 59 & $1.57 \pm 0.04 * * *, \Delta \Delta$ & $3 \times 10^{-7}$ & $128.2 \pm 5.4 * * *$ \\
\hline Peptide $3\left(3 \times 10^{-6} \mathrm{M}\right)$ & 46 & $1.06 \pm 0.08 * *, \Delta \Delta$ & $3 \times 10^{-6}$ & $122.6 \pm 1.4$ \\
\hline Peptide $4\left(3 \times 10^{-6} \mathrm{M}\right)$ & 80 & $1.22 \pm 0.03 * * *, \Delta \Delta$ & $3 \times 10^{-7}$ & $107.6 \pm 4.6$ \\
\hline Peptide $5\left(3 \times 10^{-6} \mathrm{M}\right)$ & 81 & $1.06 \pm 0.04 * *, \Delta \Delta$ & $10^{-6}$ & $90.1 \pm 1.6$ \\
\hline Peptide $6\left(3 \times 10^{-6} \mathrm{M}\right)$ & 24 & $1.96 \pm 0.08 * * *, \Delta \Delta$ & $10^{-6}$ & $114.6 \pm 5.9$ \\
\hline Peptide $7\left(3 \times 10^{-6} \mathrm{M}\right)$ & 94 & $2.75 \pm 0.09 * * *, \Delta \Delta \Delta$ & $3 \times 10^{-7}$ & $100.1 \pm 4.2$ \\
\hline Peptide $8\left(3 \times 10^{-6} \mathrm{M}\right)$ & 92 & $1.13 \pm 0.09 *, \Delta$ & $3 \times 10^{-6}$ & $92.9 \pm 8.8$ \\
\hline Peptide $9\left(3 \times 10^{-6} \mathrm{M}\right)$ & 62 & $2.47 \pm 0.12 * * *, \Delta \Delta$ & $3 \times 10^{-6}$ & $105.0 \pm 6.8$ \\
\hline Peptide $10\left(3 \times 10^{-6} \mathrm{M}\right)$ & 79 & $1.65 \pm 0.15 * * *$ & $10^{-6}$ & $106.8 \pm 4.3$ \\
\hline \multicolumn{5}{|c|}{$\begin{array}{l}* P<0.05, * * P<0.01, * * * P<0.001 \text { compared to respective control at glucose }(5.6 \mathrm{mM}) . \Delta P<0.05, \Delta \Delta P<0.01, \Delta \Delta \Delta P<0.001 \text { compared to } \\
\text { esculentin-2 } \mathrm{CHa}(1-30) \text { (Peptide 1). }\end{array}$} \\
\hline $\begin{array}{l}\text { http://joe.endocrinology-journals.org } \\
\text { DOI: } 10.1530 / \text { JOE-16-0453 }\end{array}$ & $\begin{array}{r}\text { (C) } 2017 \text { Socie } \\
\text { Pri }\end{array}$ & $\begin{array}{l}\text { ndocrinology } \\
\text { Great Britain }\end{array}$ & tifica Ltd. & \\
\hline
\end{tabular}


of esculentin-2CHa(1-30), threshold concentration for stimulating insulin release ranged between $10^{-7} \mathrm{M}$ and $3 \times 10^{-6} \mathrm{M}$ (Table 2). Insulinotropic actions of esculentin$2 \mathrm{CHa}(1-30)$ and its analogues were comparable to those of GLP-1 (Table 2).

We confirmed that the insulinotropic actions of esculentin-2 $\mathrm{CHa}(1-30)$ peptides were not due to cytotoxicity. Thus, LDH release from BRIN-BD11 cells upon exposure to the peptides was similar to that observed in control incubations (Table 2). The only exception was Peptide 2, which appeared to induce significantly greater LDH release at $3 \times 10^{-6} \mathrm{M}(P<0.001$, Table 2$)$. From the in vitro stability and insulin release studies, substitution of residues at positions 7, 15 and 23 (Peptide 6) with respective D-isomers and addition of a C-8 fatty acid to lysine residue at position 23 (Peptide 9) appeared to confer greater plasma stability and insulinotropic action on esculentin-2CHa-GA30. As a result, the native form and these two superior analogues were carried forward for further studies.

As shown in Fig. 1A, esculentin-2CHa(1-30) and its analogues (Peptide 6 and Peptide 9) markedly increased glucose stimulated insulin secretion from isolated mouse islets at $10^{-6} \mathrm{M}$ concentration $(P<0.05, P<0.01$, Fig. $1 \mathrm{~A})$. The effects induced were similar to those observed with stable forms of GLP-1 and CCK-8, namely exendin-4 and pggCCK-8, respectively $(P<0.01$, Fig. $1 \mathrm{~A})$. The insulinotropic actions were clearly glucose dependent in the case of esculentin-2CHa(1-30) peptides, which did not affect insulin secretion at $3 \mathrm{mM}$ glucose even at high concentrations (Fig. 1A). Esculentin-2CHa(1-30) (Peptide 1) and its analogues (Peptide 6 and Peptide 9) also stimulated insulin release from human clonal beta cell line, 1.1B4 $(P<0.05, P<0.01, P<0.001$, Fig. 1B). Threshold concentration for stimulation of insulin secretion from $1.1 \mathrm{~B} 4$ cells for esculentin-2 $\mathrm{CHa}(1-30)$ was $10^{-8} \mathrm{M}$, whereas threshold concentrations for modified peptides were $10^{-11} \mathrm{M}$ (Fig. 1B). The maximal effect appeared less than that induced by $10^{-6} \mathrm{M}$ exendin- 4 from 1.1B4 cells (Fig. 1B).

\section{Mechanisms underlying insulinotropic actions of esculentin-2 $\mathrm{CHa}(1-30)$ and analogues}

Effects on intracellular cAMP levels GLP-1 and forskolin markedly increased intracellular cAMP levels in BRIN-BD11 cells $(P<0.001$, Fig. $2 A)$. In contrast, esculentin-2CHa(1-30) and its analogues (Peptide 6 and 9) did not have any appreciable effect on cAMP levels (Fig. 2A).

Effects of drugs and ionic manipulation on insulinotropic activity Forskolin, PMA, GLP1, pggCCK, Peptide 1, Peptide 6 and Peptide 9 significantly increased insulin release from BRIN-BD11 cells $(P<0.05, P<0.01, P<0.001$, Fig. 2B). Chronic 18 -h exposure to PMA $(10 \mathrm{nM})$ to downregulate PKC pathways (McClenaghan et al. 2006) reduced PMA, pggCCK8, Peptide 1, Peptide 6 and Peptide 9 stimulated insulin secretion compared to routine culture
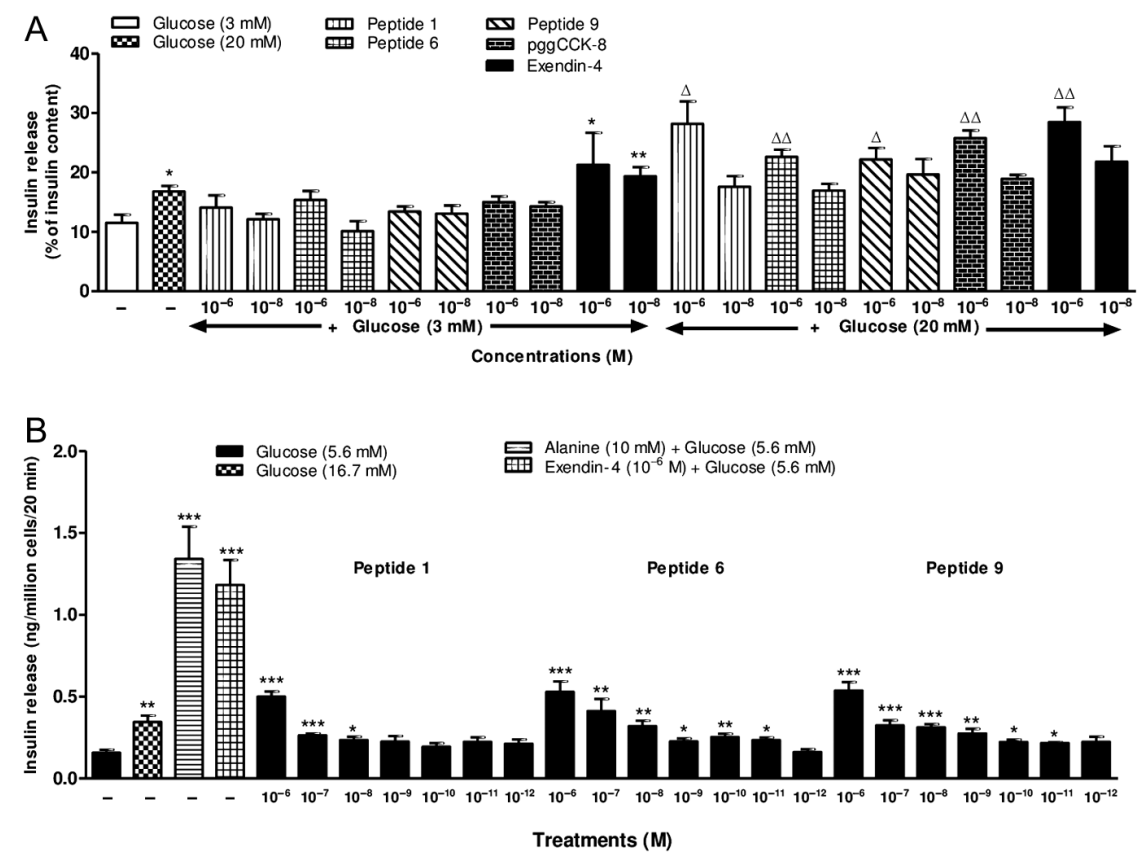
Figure 1
(A) Effects of esculentin-2CHa(1-30) (Peptide 1), [D-Arg ${ }^{7}, \mathrm{D}-\mathrm{Lys}^{15}, \mathrm{D}$-Lys ${ }^{23}$ ]-esculentin-2CHa(1-30) (Peptide 6) and Lys ${ }^{15}$-octanoate-esculentin- $2 \mathrm{CHa}(1-30)$ (Peptide 9) on insulin release from isolated mouse islets. Values are mean \pm S.E.M. $(n=4) .{ }^{*} P<0.05, * * P<0.01$ compared to glucose (3 mM). $\Delta P<0.05, \Delta \Delta P<0.01$ compared to glucose (20 mM). (B) Insulin release from human clonal 1.1B4 cells. Values are mean \pm S.E.M. $(n=4)$. $* P<0.05, * * P<0.01, * * * P<0.001$ compared to glucose $(5.6 \mathrm{mM})$.


A
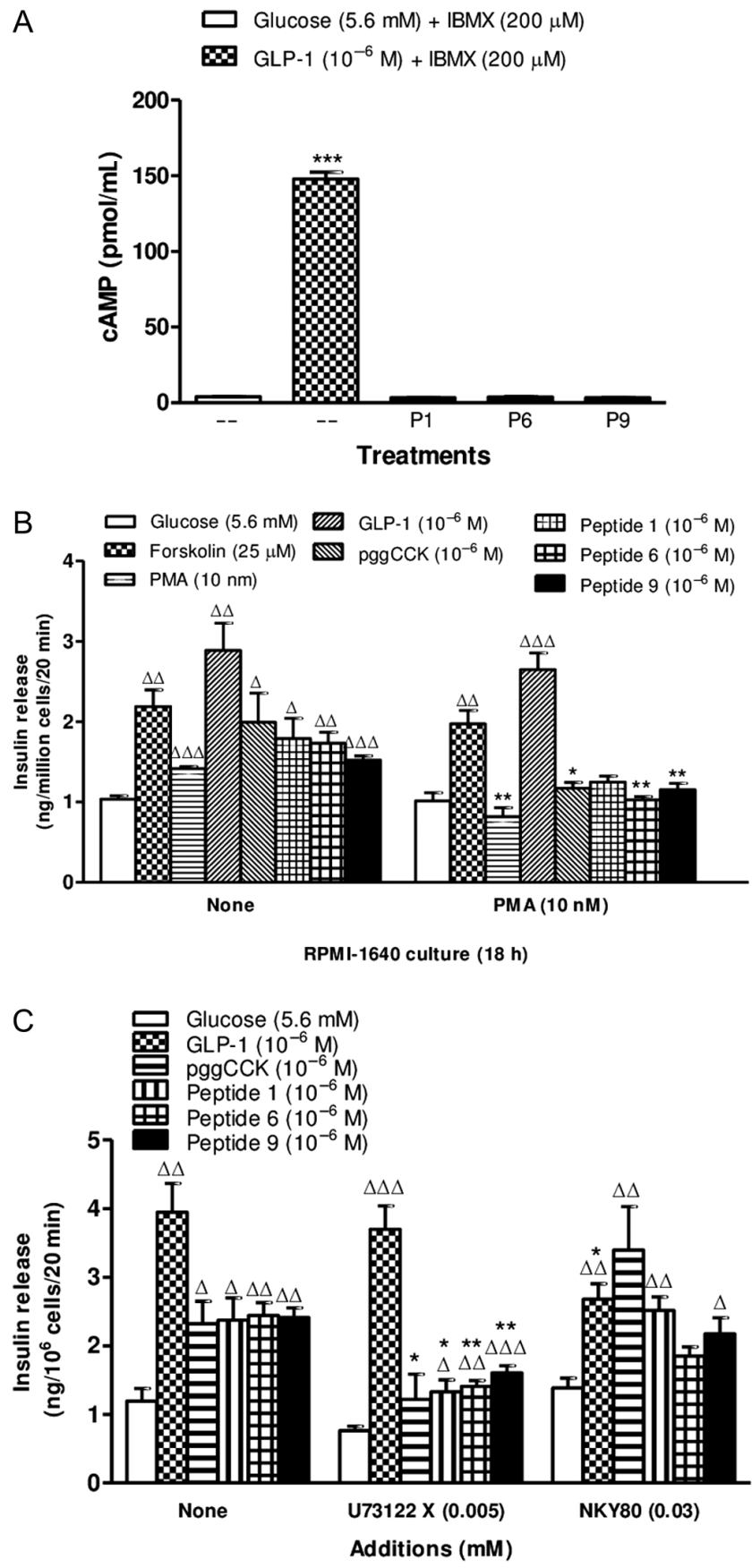

Figure 2

(A) Effects of esculentin-2CHa(1-30) (Peptide 1), [D-Arg7, D-Lys ${ }^{15}, \mathrm{D}-\mathrm{Lys}^{23}$ ]esculentin-2 $\mathrm{CHa}(1-30)$ (Peptide 6) and Lys ${ }^{15}$-octanoate-esculentin$2 \mathrm{CHa}(1-30)$ (Peptide 9) on intracellular CAMP. *** $P<0.001$ compared to glucose $(5.6 \mathrm{mM})+$ IBMX $(200 \mu \mathrm{M})$. (B) Effects of downregulation of PKC pathways using PMA on esculentin-2CHa(1-30) and related peptideinduced insulin release from BRIN-BD11 cells. (C) Effects of inhibitors of $\mathrm{PLC}$ and $\mathrm{AC}$ on esculentin-2 $\mathrm{CHa}(1-30)$ and related peptide-induced insulin release from BRIN-BD11 cells. For (B) and (C), values are mean \pm S.E.M. ( $n=4) .{ }^{*} P<0.05, * * P<0.01, * * * P<0.001$ compared to respective control (none). $\Delta P<0.05, \Delta \Delta P<0.01, \Delta \Delta \Delta P<0.001$ compared to glucose (5.6mM).
$(P<0.05, P<0.01$, Fig. 2B), In contrast, the insulinreleasing action of forskolin or GLP-1 was not attenuated. Consistent with this, the AC inhibitor, NKY80, only significantly inhibited GLP-1-induced insulin secretion $(P<0.05$, Fig. 2C), whereas the PLC inhibitor, U73122X, significantly reduced pggCCK8-, Peptide 1-, Peptide 6- and Peptide 9-induced insulin secretion $(P<0.05$, $P<0.01$, Fig. 3A). The insulinotropic effect of GLP-1 was not impaired by U73122X. As esculentin-2CHa(1-30) peptides still evoked small increase of insulin release in the presence of NKY80, ionic pathways involved in insulin secretion were investigated.

Verapamil and diazoxide did not affect basal insulin secretion, whereas IBMX, $\mathrm{KCl}$ and tolbutamide markedly increased insulin release from BRIN-BD11 cells $(P<0.05$, $P<0.01$, Fig. 3A). Verapamil reduced pggCCK8-, Peptide 1 - and Peptide 9-induced insulin secretion $(P<0.05$, Fig. 3A), whereas diazoxide reduced the insulinotropic effects of GLP-1, pggCCK8, Peptide 1 and Peptide 9 compared to control $(P<0.05, P<0.01, P<0.001$, Fig. $3 \mathrm{~A})$. Peptide 6 potentiated IBMX-induced insulin secretion $(P<0.05$, Fig. 3A), whereas none of the peptides altered the stimulatory insulin-secretory responses from cells depolarised with $30 \mathrm{mM} \mathrm{KCl} \mathrm{(Fig.} \mathrm{3A).} \mathrm{GLP-1} \mathrm{and} \mathrm{all}$ peptides tested potentiated insulin secretion in the presence of tolbutamide $(P<0.05$, Fig. 3A). Insulinotropic actions of GLP-1, pggCCK8 and all esculentin-2CHa(1-30) peptides were abolished in the absence of extracellular $\mathrm{Ca}^{2+}$ (Fig. 3B).

\section{Effects on membrane potential and intracellular}

$\mathbf{C a}^{2+}$ Esculentin-2CHa(1-30) and its analogues (Peptides 6 and 9) increased membrane potential and depolarised BRIN-BD11 cells compared to $5.6 \mathrm{mM}$ glucose control $(P<0.05, P<0.01, P<0.001$, Fig. $4 \mathrm{~A}$ and $\mathrm{B})$. This was accompanied by a significant increase in intracellular $\left[\mathrm{Ca}^{2+}\right]_{\mathrm{i}}(P<0.05, P<0.001$, Fig. $4 \mathrm{C}$ and $\mathrm{D})$. The magnitude of the effects was markedly less than that induced by a depolarising concentration of $\mathrm{KCl}$ but similar to GLP-1 (Fig. 4).

Actions at plasma membrane FITC-esculentin$2 \mathrm{CHa}(1-30)$ was used to monitor the interactions of the peptide at plasma membrane sites on BRIN-BD11 cells. Representative images showing cells incubated for 5-90 min with the fluorescent-tagged peptide are shown in Fig. 5. Membrane binding by FITC-esculentin-2CHa(1-30) was evident on the http://joe.endocrinology-journals.org DOI: $10.1530 / \mathrm{JOE}-16-0453$
() 2017 Society for Endocrinology Printed in Great Britain 
A

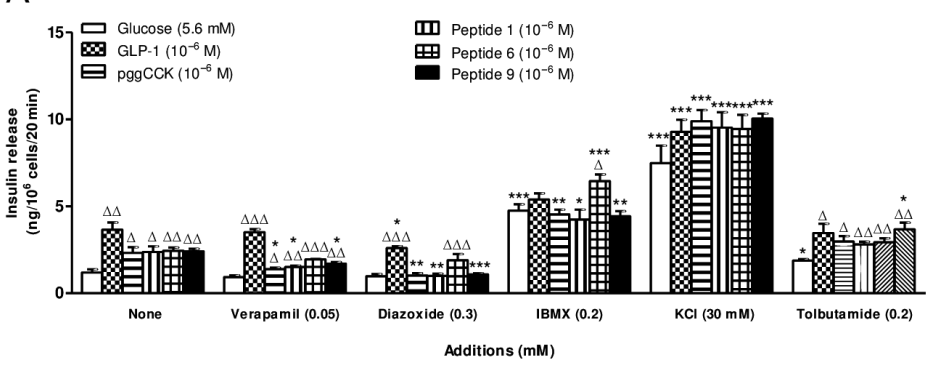

B Glucose $(5.6 \mathrm{mM})$

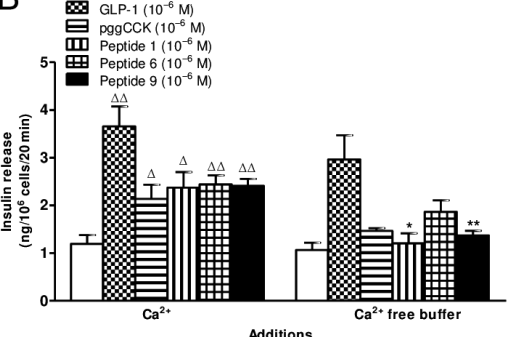

Figure 3

(A) Effects of known modulators of beta cell function on esculentin-2CHa(1-30) (Peptide 1), [D-Arg ${ }^{7}, \mathrm{D}-\mathrm{Lys}^{15}{ }^{15} \mathrm{D}-\mathrm{Lys}^{23}$ ]-esculentin-2CHa(1-30) (Peptide 6) and Lys ${ }^{15}$-octanoate-esculentin-2CHa(1-30) (Peptide 9) induced insulin release from BRIN-BD11 cells. (B) Insulin release in the presence or absence of extracellular $\mathrm{Ca}^{2+}$. Values are mean \pm S.E.M. $(n=4) .{ }^{*} P<0.05, * * P<0.01, * * * P<0.001$ compared to respective control (none). $\Delta P<0.05, \Delta \Delta P<0.01$, $\triangle \triangle \triangle P<0.001$ compared to glucose $(5.6 \mathrm{mM})$

membrane of discrete populations of cells after 5-min exposure, while fluorescence in cytoplasm of cells was also evident after 20-min incubation becoming progressively more intense over time up to $90 \mathrm{~min}$, suggesting initial binding with the membrane followed by internalisation of the peptide. To probe further the membrane effects underlying changes in membrane potential and intracellular $\mathrm{Ca} 2+$, we examined the actions of [D-Arg 7 ,D-Lys ${ }^{15}$,D-Lys ${ }^{23}$ esculentin-2CHa(1-30) (Peptide 6) on BRIN-BD11 cells using patch-clamp technique. This revealed that the depolarisation observed in Fig. 4A was unlikely to be due to direct action of the peptide on $\mathrm{K}_{\text {ATP }}$ channels as when membrane current was recorded under selective recording conditions using the patch-clamp technique, Peptide $6(1 \mu \mathrm{M})$ had no effect on the amplitude of diazoxide-activated $\mathrm{K}_{\mathrm{ATP}}$ current measured at $-80 \mathrm{mV}$
(Fig. 6A) or mean current density at voltages between 20 and $-80 \mathrm{mV}(P>0.05$, Fig. $6 \mathrm{~B}$ and $\mathrm{C})$.

\section{Acute anti-hyperglycaemic activity of esculentin- $2 \mathrm{CHa}(1-30)$ and analogues}

As shown in Fig. 7A and B, Peptide 6 and Peptide 9 significantly reduced the glycaemic excursion $(P<0.05)$ when administered together with glucose to overnight fasted NIH Swiss TO mice. This was associated with elevated insulin concentrations, with Peptide 9 significantly increasing integrated (AUC) plasma insulin values $(P<0.01$, Fig. $7 \mathrm{C}$ and $\mathrm{D})$. The effects observed were broadly similar to those induced by an equal dose of GLP-1 (Fig. 7A, B, C and D). Follow-up dose-response studies revealed that $75 \mathrm{nmol} / \mathrm{kg}$ body weight was the minimal effective anti-hyperglycaemic dose of GLP-1,

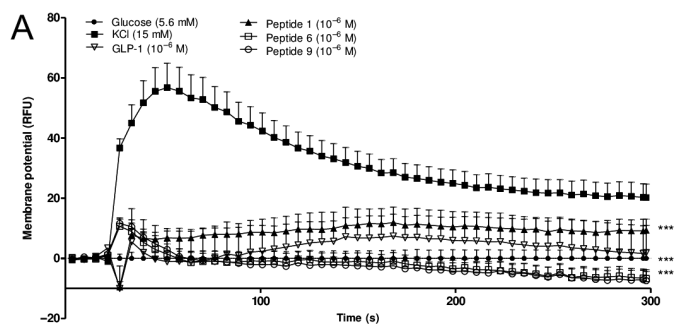

B
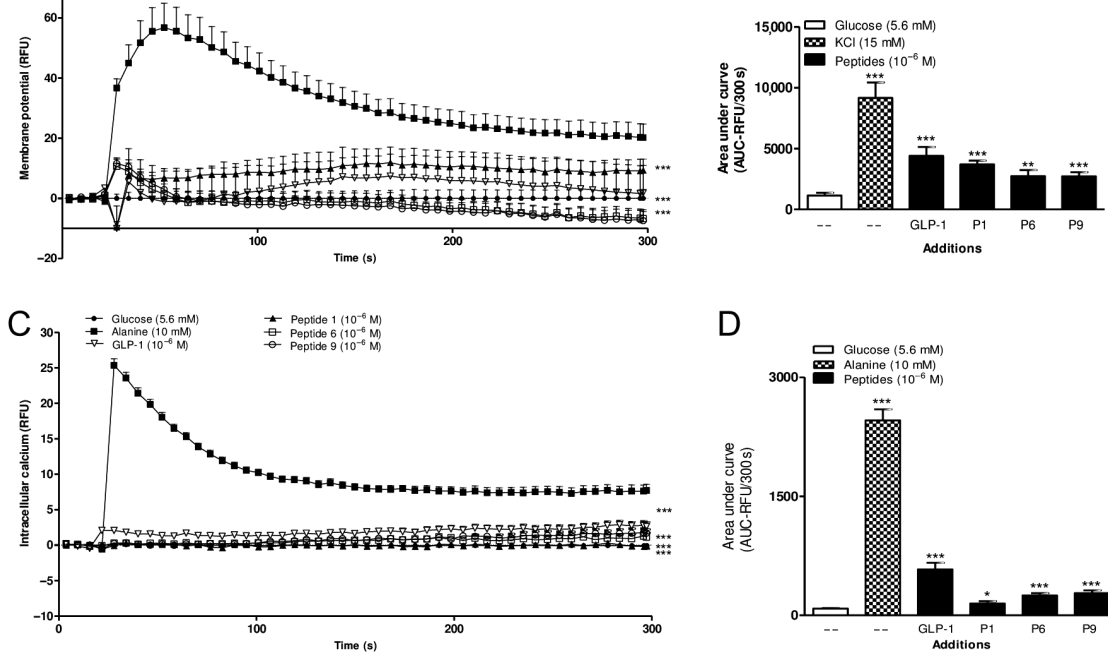

D

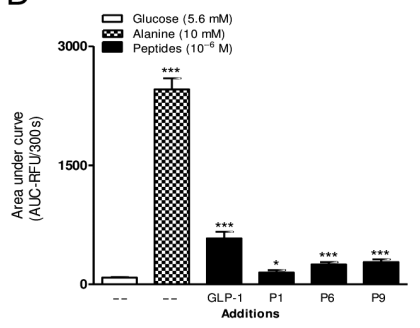

Figure 4

Effects of esculentin-2CHa(1-30) (Peptide 1), [D-Arg ${ }^{7}, \mathrm{D}-\mathrm{Lys}^{15}{ }^{15}$ D-Lys ${ }^{23}$ ]-esculentin-2CHa(1-30) (Peptide 6) and Lys ${ }^{15}$-octanoate-esculentin2CHa(1-30) (Peptide 9) on (A and B) membrane potential and intracellular $\mathrm{Ca}^{2+}$ in BRIN-BD11 cells, expressed as ( $A$ and $C$ ) relative fluorescent units (RFU) and ( $B$ and $D$ ) area under curve. Values are mean \pm S.E.M. $(n=12) . * P<0.05, * * P<0.01$,

$\star * * P<0.001$ compared to glucose $(5.6 \mathrm{mM})$. 

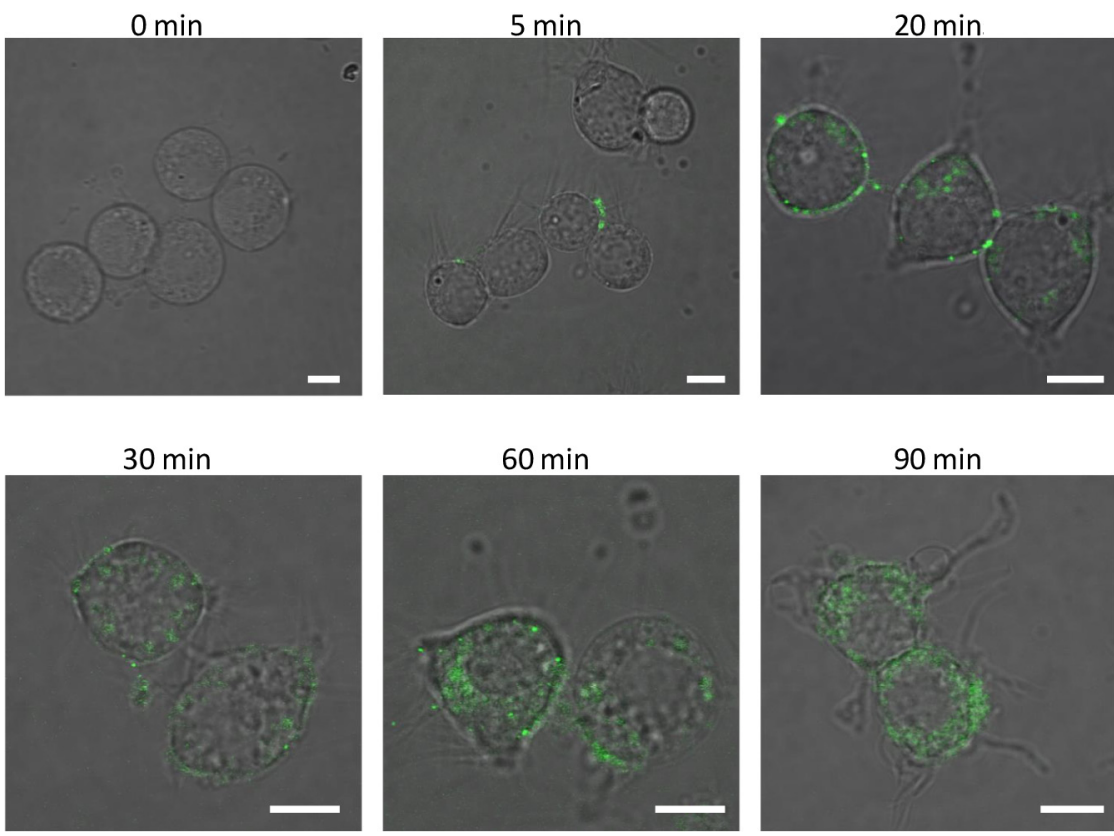

Figure 5

Representative confocal images (overlaid with transmitted light images) of BRIN-BD11 cells before $(0 \mathrm{~min})$ and after exposure to FITCEsculentin-2CHa(1-30) for 5-90 min showing progressive internalisation of FITC-esculentin$2 \mathrm{CHa}(1-30)$ over time. Scale bars $10 \mu \mathrm{m}$.
Peptide 6 or Peptide 9 under the experimental conditions employed $(P<0.05$, Fig. 7E).

\section{Discussion}

Genetic influences and lifestyle factors promote the constantly increasing incidence of type 2 diabetes, which is treated clinically by strategies that target pancreatic beta cell dysfunction and/or insulin resistance (Bailey 2009, Irwin \& Flatt 2015). Recently, peptide therapeutics for diabetes using stable mimetics of GLP-1 have received much attention due to their tolerability, potency and efficacy compared to small-molecules drugs. Our recent observations reveal that esculentin-2CHa possesses potent insulinotropic actions and an analogue ([Lys $\left.{ }^{28}\right]-$ esculentin-2CHa) exerted beneficial effects on metabolism in high-fat-fed mice with insulin resistance and impaired glucose tolerance (Ojo et al. 2015). We have observed that esculentin-2CHa(1-30), a truncated and more readily synthesised analogue of 30 amino acids lacking the cyclic C-terminal domain, retains the insulin-releasing activity. The present study investigates the stability, insulinotropic actions and mechanisms of insulin secretion of esculentin$2 \mathrm{CHa}(1-30)$ and designer analogues together with their possible development for treatment of type 2 diabetes.

In vitro plasma degradation studies revealed that substitution with D-isomers of residues at position 7 (Peptide 2), position 15 (Peptide 3) and positions 7, 15, 23 (Peptide 6) and addition of a C-8 fatty acid to lysine residue at position 15 (Peptide 9) or position 23 (Peptide 10) enhanced resistance to degradation by plasma proteolytic enzymes. Peptides 6, 9 and 10 were partially degraded to 3 fragments after 8-h incubation with mouse
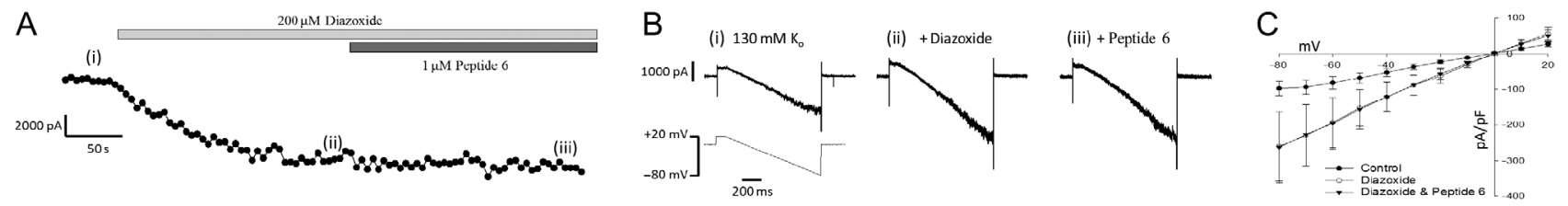

\section{Figure 6}

[D-Arg7,D-Lys ${ }^{15}, \mathrm{D}-\mathrm{Lys}^{23}$ ]-esculentin-2CHa(1-30) (Peptide 6) has no effect on $\mathrm{K}_{\text {ATP }}$ channels in BRIN-BD11 pancreatic $\beta$ cells. (A) Membrane current recorded at $-80 \mathrm{mV}$ obtained during voltage ramp protocols applied every $5 \mathrm{~s}$, plotted before and during the application of the $\mathrm{K}_{\mathrm{ATP}}$ channel activator, diazoxide, in the absence and presence of esculentin-2CHa(1-30) (Peptide 6). (B) Representative traces showing currents at points indicated on A generated by the application of the voltage ramp protocol illustrated in the lower panel (1 s ramp from +20 to $-80 \mathrm{mV}$ applied every $5 \mathrm{~s}$ ) under (i) control conditions $\left(130 \mathrm{mM}\right.$ external $\left.\mathrm{K}^{+}\right)$, (ii) after application of the $\mathrm{K}_{\text {ATP }}$ channel activator, diazoxide $(200 \mu \mathrm{M})$, and (iii) esculentin-2CHa(1-30) (Peptide $\left.6,1 \mu \mathrm{M}\right)$ in the continued presence of diazoxide. (C) Current-voltage relationships (mean \pm S.E.M.) from 8 cells normalised to cell capacitance measured at $10 \mathrm{mV}$ intervals during the voltage ramp. Esculentin-2CHa(1-30) (Peptide 6) had no effect on the $\mathrm{K}_{\text {ATP }}$ current activated by diazoxide $(P>0.05 ; 2$-way repeated measures ANOVA). 

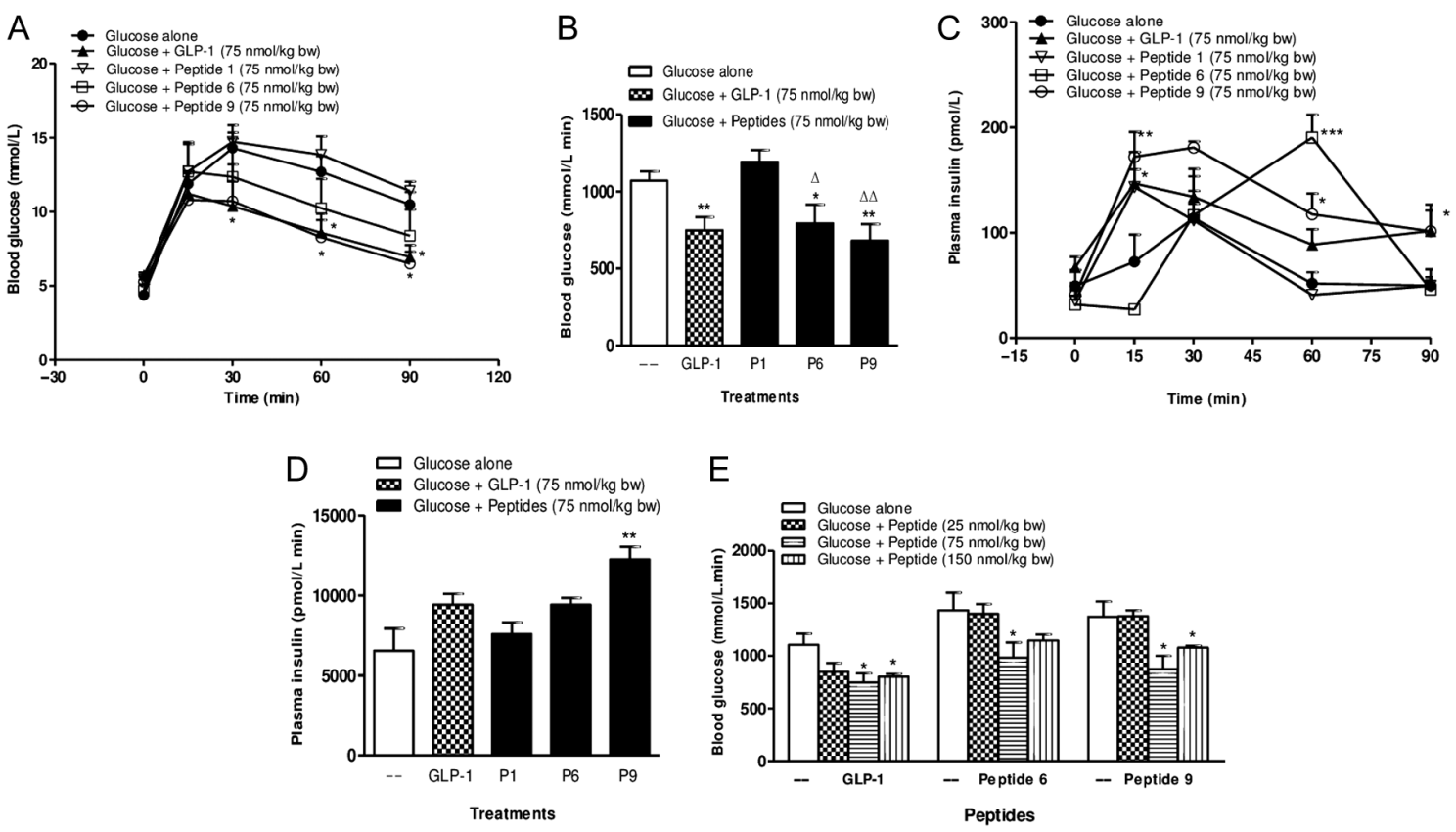

\section{Figure 7}

Acute in vivo effects of esculentin-2CHa(1-30) (Peptide 1), [D-Arg $, \mathrm{D}^{-L y s}{ }^{15}, \mathrm{D}-\mathrm{Lys}^{23}$ ]-esculentin-2CHa(1-30) (Peptide 6) and Lys ${ }^{15}$-octanoate-esculentin$2 \mathrm{CHa}(1-30)$ (Peptide 9) on glucose tolerance, expressed as (A) line graph and (B) area under curve ( $\mathrm{mmol} / \mathrm{Lmin}$ ). Plasma insulin responses expressed as (C) line graph and (D) area under curve (pmol/L min). (E) Dose-dependent effects of GLP-1, Peptide 6 and Peptide 9 on glucose tolerance, expressed as the integrated glucose response (area under curve: $\mathrm{mmol} / \mathrm{L} \mathrm{min}$ ). ${ }^{*} P<0.05,{ }^{*} P<0.01$ compared to glucose alone. $\Delta P<0.05$ compared to esculentin$2 \mathrm{CHa}(1-30)$ (Peptide 1).

plasma, whereas esculentin-2CHa(1-30) was degraded to 5 fragments. Enhanced resistance to degradation coupled with intact insulinotropic activity may be beneficial in vivo. Indeed, insulinotropic actions of modified analogues were well preserved in clonal BRIN-BD11 cells. These actions were not associated with cellular cytotoxicity as indicated by lack of leakage of the intracellular marker LDH.

On the basis of enzymatic stability and insulinreleasing potency, three peptides were chosen for further evaluation, namely the analogue with triple D-isomer substitution (Peptide 6), the acylated form of esculentin2CHa(1-30) (Peptide 9) and for comparison the parent molecule, esculentin-2CHa(1-30) (Peptide 1). Studies using isolated mouse islets highlighted the glucosedependent insulin-releasing properties of all three peptides, which exerted effects similar to those of stable analogues of GLP- 1 and CCK-8 (exendin- 4 and pggCCK-8, respectively). When tested using the novel electrofusionderived human 1.1B4 cell line (McCluskey et al. 2011), the esculentin-2CHa(1-30) peptides stimulated concentration-dependent insulin secretion with lower threshold stimulatory concentrations being observed for the modified analogues. These data indicate that the peptides should not induce hypoglycaemia and that they are likely to stimulate insulin secretion from human beta cells, with translational effects in vivo.

Beta cell stimulus secretion coupling is a complex process, with the involvement of many key players including $\mathrm{K}_{\mathrm{ATP}}$ channels, ATP, PKA, PKC, cAMP, $\mathrm{Ca}^{2+}$, functional microtubule and microfilament system (McClenaghan 2007, Fu et al. 2013). Beta cells detect the changes in blood glucose levels, and subsequent metabolism leads to increase in ATP levels that induces closure of plasma membrane $\mathrm{K}_{\mathrm{ATP}}$ channels and depolarisation resulting in the opening of voltage-gated $\mathrm{Ca}^{2+}$ channels (VDCC) (McClenaghan 2007, Drews et al. 2010, Fu et al. 2013). $\mathrm{Ca}^{2+}$ oscillations stimulate pulsatile insulin secretion with exocytosis of secretory granules, which accounts for the first and early phase of insulin secretion. $\mathrm{K}_{\text {ATP }}$ channel-independent mechanisms $\left(\mathrm{Ca}^{2+}\right.$ dependent or independent) mediate the second phase of insulin secretion. The $\mathrm{K}_{\text {АTP }}$ channel-dependent pathway is considered to be the major trigger for glucosestimulated insulin secretion (GSIS), with amplification by pathways triggered by adenylate cyclase (cAMP, PKA) or phospholipase C (PKC) (Yaney et al. 2002, Doyle \& Egan 2007).

Inhibitors of enzymes (AC and PLC) and ion channels $\left(\mathrm{K}_{\mathrm{ATP}}, \mathrm{VDCC}\right)$, fluorescent dyes to monitor membrane 
potential and intracellular $\mathrm{Ca}^{2+}$, measurement of second messengers such as cyclic AMP and electrophysiological techniques are useful to delineate mechanisms underlying the insulinotropic actions of novel peptides and drugs (Yaney et al. 2002, Miguel et al. 2004, Drews et al. 2010, Hodson et al. 2014). We used these strategies to understand better the actions through which esculentin$2 \mathrm{CHa}(1-30)$ and its selected analogues elicited insulin secretion using BRIN-BD11 cells. Direct measurement of cyclic AMP showed that unlike GLP-1 (Dyachok et al. 2006, Ramos et al. 2008), esculentin-2CHa(1-30) peptides had little effect on cyclic AMP, resembling the actions of CCK-8. Consistent with this, downregulation of PKC pathway after overnight culture with PMA (Yaney et al. 2002) significantly reduced PMA-, GLP-1-, pggCCK8-, Peptide 1-, Peptide 6- and Peptide 9-induced insulin secretion. Similarly AC inhibition using NKY80 reduced GLP-1-induced insulin release but not the stimulatory effects of pggCCK8 or esculentin-2CHa(1-30) peptides.

To establish the involvement of ionic events, we studied the actions of diazoxide, high $\mathrm{K}^{+}$solution, verapamil and depletion of $\mathrm{Ca}^{2+}$ on the effects of esculentin$2 \mathrm{CHa}(1-30)$ peptides. Each of these conditions inhibited the insulinotropic response. Consistent with these data, the insulin-secretory effects of the peptides on BRIN-BD11 cells were accompanied by depolarisation and increased intracellular $\mathrm{Ca}^{2+}$. Collectively, these findings suggested to us that the insulinotropic effects of esculentin-2CHa(1-30) peptides might result, at least in part, from the inhibition of $\mathrm{K}_{\mathrm{ATP}}$ channels to cause depolarisation and voltagedependent $\mathrm{Ca}^{2+}$ influx. In patch-clamp experiments, however, we found that esculentin-2CHa(1-30) peptides had no direct effect on beta cell $\mathrm{K}_{\mathrm{ATP}}$ channels. This raises the possibility of an action on other ion channels such as L-type $\mathrm{Ca}^{2+}$ channels a direct depolarising effect resulting from positively charged peptides entering the beta cell as suggested by imaging studies using fluorescently tagged FITC-esculentin-2CHa(1-30). Further studies will be required to evaluate such effects and the consequences of longer term exposure of beta cells to these peptides.

Cell-penetrating peptides are receiving increasing interest as vehicles for intracellular delivery of therapeutic agents such as anti-cancer drugs (Kurrikoff et al. 2016). The relatively rapid and efficient internalisation of FITCesculentin-2CHa(1-30) by BRIN-BD11 cells, without loss of integrity of the plasma membrane, suggests a possible application for enzyme-resistant analogues of the peptide. In this regard, esculentin-2CHa(1-30) resembles the amphibian histone H2A-derived peptide buforin II (Elmore 2012). Buforin II traverses the cell membrane in a cooperative manner without producing significant damage by a mechanism that involves the formation of transient toroidal pore structures. Once internalised, buforin II accumulates in the nucleus and alters cellular function (Lee et al. 2008). Studies in vivo (unpublished data) have shown that treatment of high-fat-fed mice with esculentin-2 $\mathrm{CHa}(1-30)$ and its analogues ameliorates diabetes and has beneficial effects on the expression of pancreatic islet genes involved with insulin release suggesting that the internalised peptide may also be able to regulate transcription.

In conclusion, the present study has shown that analogues of esculentin-2CHa(1-30), namely [D-Arg $\left.{ }^{7}, \mathrm{D}-\mathrm{Lys}^{15}{ }^{15} \mathrm{D}-\mathrm{Lys}^{23}\right]$-esculentin-2CHa(1-30) and Lys ${ }^{15}$ octanoate-esculentin-2CHa(1-30) (Peptides 6 and 9, respectively demonstrate enhanced resistance to degradation by endopeptidases and strong insulinotropic actions on rat and human clonal beta cells as well as primary mouse islets. These peptide analogues also exerted anti-hyperglycaemic effects and promoted glucose-induced insulin release in normal mice. Detailed studies investigating the effects of chronic administration of these peptides in animal models of obesity-diabetes are needed to further explore the potential of esculentin$2 \mathrm{CHa}(1-30)$ analogues for therapy of diabetes in man.

\section{Declaration of interest}

The authors declare that there is no conflict of interest that could be perceived as prejudicing the impartiality of the research reported.

\section{Funding}

Funding for this study was provided by a proof-of-concept project grant from Invest NI (grant number POC 418) and project grant from Diabetes UK.

\section{Author contribution statement}

$\mathrm{S} V, M K M$ and $\mathrm{R} C \mathrm{M}$ performed the experiments, analysed data and prepared the manuscript. T M C, J M C, Y H A A and P R F conceived and designed the study and prepared the manuscript.

\section{References}

Abdel-Wahab YH, Power GJ, Ng MT, Flatt PR \& Conlon JM 2008 Insulinreleasing properties of the frog skin peptide pseudin-2 and its [Lys18]substituted analogue. Biological Chemistry 389 143-148. (doi:10.1515/ BC.2008.018)

Attoub S, Mechkarska M, Sonnevend A, Radosavljevic G, Jovanovic I, Lukic ML \& Conlon JM 2013 Esculentin-2CHa: a host-defense peptide with differential cytotoxicity against bacteria, erythrocytes and tumor cells. Peptides 39 95-102. (doi:10.1016/j.peptides.2012.11.004)

Published by Bioscientifica Ltd. 
Bailey CJ 2009 New therapies for diabesity. Current Diabetes Reports 9 360-367. (doi:10.1007/s11892-009-0057-y)

Conlon JM 2008 Reflections on a systematic nomenclature for antimicrobial peptides from the skins of frogs of the family Ranidae. Peptides 29 1815-1819. (doi:10.1016/j.peptides.2008.05.029)

Conlon JM 2011 Structural diversity and species distribution of hostdefense peptides in frog skin secretions. Cellular and Molecular Life Sciences 68 2303-2315. (doi:10.1007/s00018-011-0720-8)

Conlon JM \& Mechkarska M 2014 Host-defense peptides with therapeutic potential from skin secretions of frogs from the family pipidae. Pharmaceuticals 15 58-77. (doi:10.3390/ph7010058)

Conlon JM, Patterson S \& Flatt PR 2006 Major contributions of comparative endocrinology to the development and exploitation of the incretin concept. Journal of Experimental Zoology Part A: Ecological Genetics and Physiology 305 781-786. (doi:10.1002/jez.a.312)

Conlon JM, Mechkarska M, Coquet L, Jouenne T, Leprince J, Vaudry H, Kolodziejek J, Nowotny N \& King JD 2011 Characterization of antimicrobial peptides in skin secretions from discrete populations of Lithobates chiricahuensis (Ranidae) from central and southern Arizona. Peptides 32 664-669. (doi:10.1016/j.peptides.2011.01.018)

Conlon JM, Mechkarska M, Lukic ML \& Flatt PR 2014 Potential therapeutic applications of multifunctional host-defense peptides from frog skin as anti-cancer, anti-viral, immunomodulatory, and anti-diabetic agents. Peptides 57 67-77. (doi:10.1016/j. peptides.2014.04.019)

Doyle ME \& Egan JM 2007 Mechanisms of action of glucagon-like peptide 1 in the pancreas. Pharmacology and Therapeutics 113 546-593. (doi:10.1016/j.pharmthera.2006.11.007)

Drews G, Krippeit-Drews P \& Dufer M 2010 Electrophysiology of islet cells. Advances in Experimental Medicine and Biology 654 115-163. (doi:10.1007/978-90-481-3271-3_7)

Dyachok O, Isakov Y, Sagetorp J \& Tengholm A 2006 Oscillations of cyclic AMP in hormone-stimulated insulin-secreting beta-cells. Nature 439 349-352. (doi:10.1038/nature04410)

Elmore DE 2012 Insights into buforin II membrane translocation from molecular dynamics simulations. Peptides 38 357-362. (doi:10.1016/j. peptides.2012.09.022)

Flatt PR \& Bailey CJ 1981a Abnormal plasma glucose and insulin responses in heterozygous lean (ob/+) mice. Diabetologia 20 573-577. (doi:10.1007/bf00252768)

Flatt PR \& Bailey CJ $1981 b$ Development of glucose intolerance and impaired plasma insulin response to glucose in obese hyperglycaemic (ob/ob) mice. Hormone and Metabolic Research 13 556-560. (doi:10.10 55/s-2007-1019334)

Fu A, Eberhard CE \& Screaton RA 2013 Role of AMPK in pancreatic beta cell function. Molecular and Cellular Endocrinology 366 127-134. (doi:10.1016/j.mce.2012.06.020)

Gotoh M, Maki T, Kiyoizumi T, Satomi S \& Monaco AP 1985 An improved method for isolation of mouse pancreatic islets. Transplantation $\mathbf{4 0}$ 437-438. (doi:10.1097/00007890-198510000-00018)

Green AD, Vasu S, McClenaghan NH \& Flatt PR 2015 Pseudoislet formation enhances gene expression, insulin secretion and cytoprotective mechanisms of clonal human insulin-secreting 1.1B4 cells. Pflügers Archiv 467 2219-2228. (doi:10.1007/s00424-014-1681-1)

Hodson DJ, Tarasov AI, Gimeno Brias S, Mitchell RK, Johnston NR, Haghollahi S, Cane MC, Bugliani M, Marchetti P, Bosco D, et al. 2014 Incretin-modulated beta cell energetics in intact islets of Langerhans. Molecular Endocrinology 28 860-871. (doi:10.1210/me.2014-1038)

Irwin N \& Flatt PR 2015 New perspectives on exploitation of incretin peptides for the treatment of diabetes and related disorders. World Journal of Diabetes 6 1285-1295. (doi:10.4239/wjd.v6.i15.1285)

Irwin N, Frizelle P, O'Harte FP \& Flatt PR 2013 (pGlu-Gln)-CCK-8[mPEG]: a novel, long-acting, mini-PEGylated cholecystokinin (CCK) agonist that improves metabolic status in dietary-induced diabetes. Biochimica et Biophysica Acta 1830 4009-4016. (doi:10.1016/j. bbagen.2013.04.004)
Jackway RJ, Pukala TL, Donnellan SC, Sherman PJ, Tyler MJ \& Bowie JH 2011 Skin peptide and cDNA profiling of Australian anurans: genus and species identification and evolutionary trends. Peptides $\mathbf{3 2}$ 161-172. (doi:10.1016/j.peptides.2010.09.019)

Kahn SE, Cooper ME \& Del Prato S 2014 Pathophysiology and treatment of type 2 diabetes: perspectives on the past, present, and future. Lancet 383 1068-1083. (doi:10.1016/S0140-6736(13)62154-6)

Kurrikoff K, Gestin M \& Langel Ü 2016 Recent in vivo advances in cellpenetrating peptide-assisted drug delivery. Expert Opinion on Drug Delivery 13 373-387. (doi:10.1517/17425247.2016.1125879)

Lee HS, Park CB, Kim JM, Jang SA, Park IY, Kim MS, Cho JH \& Kim SC 2008 Mechanism of anticancer activity of buforin IIb, a histone H2A-derived peptide. Cancer Letters 271 47-55. (doi:10.1016/j. canlet.2008.05.041)

McCarthy MI 2011 Dorothy Hodgkin Lecture 2010. From hype to hope? A journey through the genetics of Type 2 diabetes. Diabetic Medicine 28 132-140. (doi:10.1111/j.1464-5491.2010.03194.x)

McClenaghan NH 2007 Physiological regulation of the pancreatic \{beta\}-cell: functional insights for understanding and therapy of diabetes. Experimental Physiology 92 481-496. (doi:10.1113/ expphysiol.2006.034835)

McClenaghan NH, Barnett CR, Ah-Sing E, Abdel-Wahab YH, O'Harte FP, Yoon TW, Swanston-Flatt SK \& Flatt PR 1996 Characterization of a novel glucose-responsive insulin-secreting cell line, BRIN-BD11, produced by electrofusion. Diabetes 45 1132-1140. (doi:10.2337/ diab.45.8.1132)

McClenaghan NH, Flatt PR \& Ball AJ 2006 Actions of glucagon-like peptide-1 on KATP channel-dependent and -independent effects of glucose, sulphonylureas and nateglinide. Journal of Endocrinology 190 889-896. (doi:10.1677/joe.1.06949)

McCluskey JT, Hamid M, Guo-Parke H, McClenaghan NH, Gomis R $\&$ Flatt PR 2011 Development and functional characterization of insulin-releasing human pancreatic beta cell lines produced by electrofusion. Journal of Biological Chemistry 286 21982-21992. (doi:10.1074/jbc.M111.226795)

Mechkarska M, Ahmed E, Coquet L, Leprince J, Jouenne T, Vaudry H, King JD \& Conlon JM 2010 Antimicrobial peptides with therapeutic potential from skin secretions of the Marsabit clawed frog Xenopus borealis (Pipidae). Comparative Biochemistry and Physiology Part C: Toxicology and Pharmacology 152 467-472. (doi:10.1016/j.cbpc.2010.07.007)

Mechkarska M, Ojo OO, Meetani MA, Coquet L, Jouenne T, Abdel-Wahab YH, Flatt PR, King JD \& Conlon JM 2011 Peptidomic analysis of skin secretions from the Lithobates catesbeianus (Ranidae) identifies multiple peptides with potent insulin-releasing activity. Peptides 32 203-208. (doi:10.1016/j.peptides.2010.11.002)

Miguel JC, Patterson S, Abdel-Wahab YH, Mathias PC \& Flatt PR 2004 Time-correlation between membrane depolarization and intracellular calcium in insulin secreting BRIN-BD11 cells: studies using FLIPR. Cell Calcium 36 43-50. (doi:10.1016/j.ceca.2003.11.007)

Nicolas P \& El Amri C 2009 The dermaseptin superfamily: a genebased combinatorial library of antimicrobial peptides. Biochimica et Biophysica Acta 1788 1537-1550. (doi:10.1016/j.bbamem.2008.09.006)

O'Harte FP, Mooney MH, Kelly CM, McKillop AM \& Flatt PR 2001 Degradation and glycemic effects of His(7)-glucitol glucagon-like peptide-1(7-36)amide in obese diabetic ob/ob mice. Regulatory Peptides 96 95-104. (doi:10.1016/s0167-0115(00)00125-7)

Ojo OO, Abdel-Wahab YH, Flatt PR, Mechkarska M \& Conlon JM 2011 Tigerinin-1R: a potent, non-toxic insulin-releasing peptide isolated from the skin of the Asian frog, Hoplobatrachus rugulosus. Diabetes, Obesity and Metabolism 13 1114-1122. (doi:10.1111/j.14631326.2011.01470.x)

Ojo OO, Srinivasan DK, Owolabi BO, Vasu S, Conlon JM, Flatt PR \& Abdel-Wahab YH 2015 Esculentin-2CHa-related peptides modulate islet cell function and improve glucose tolerance in mice with diet-induced obesity and insulin resistance. PLOS ONE 10 e0141549. (doi:10.1371/journal.pone.0141549) 
Ojo OO, Srinivasan DK, Owolabi BO, McGahon MK, Moffett RC, Curtis TM, Conlon JM, Flatt PR \& Abdel-Wahab YH 2016 Molecular mechanisms mediating the beneficial metabolic effects of [Arg4] tigerinin-1R in mice with diet-induced obesity and insulin resistance. Biological Chemistry 397 753-764. (doi:10.1515/hsz2016-0120)

Owolabi BO, Ojo OO, Srinivasan DK, Conlon JM, Flatt PR \& Abdel-Wahab YH 2016 In vitro and in vivo insulinotropic properties of the multifunctional frog skin peptide hymenochirin-1B: a structure-activity study. Amino Acids 48 535-547. (doi:10.1007/ s00726-015-2107-x)

Parkes DG, Mace KF \& Trautmann ME 2013 Discovery and development of exenatide: the first antidiabetic agent to leverage the multiple benefits of the incretin hormone, GLP-1. Expert Opinion on Drug Discovery 8 219-244. (doi:10.1517/17460441.2013.741580)
Ramos LS, Zippin JH, Kamenetsky M, Buck J \& Levin LR 2008 Glucose and GLP-1 stimulate cAMP production via distinct adenylyl cyclases in INS-1E insulinoma cells. Journal of General Physiology 132 329-338. (doi:10.1085/jgp.200810044)

Scholfield CN \& Curtis TM 2000 Heterogeneity in cytosolic calcium regulation among different microvascular smooth muscle cells of the rat retina. Microvascular Research 59 233-242. (doi:10.1006/mvre.1999.2227)

Stumvoll M, Goldstein BJ \& van Haeften TW 2008 Type 2 diabetes: pathogenesis and treatment. Lancet 371 2153-2156. (doi:10.1016/ S0140-6736(08)60932-0)

Yaney GC, Fairbanks JM, Deeney JT, Korchak HM, Tornheim K \& Corkey BE 2002 Potentiation of insulin secretion by phorbol esters is mediated by PKC-alpha and nPKC isoforms. American Journal of Physiology: Endocrinology and Metabolism 283 E880-E888. (doi:10.1152/ajpendo.00474.2001)

Received in final form 13 December 2016

Accepted 3 January 2017
๑) 2017 Society for Endocrinology Printed in Great Britain
Published by Bioscientifica Ltd. 